\title{
The Influence of Tail Biting on Performance of Fattening Pigs
}

\author{
By P. Wallgren and E. Lindahl \\ National Veterinary Institute, Uppsala, Sweden.
}

\begin{abstract}
Wallgren, P. and E. Lindahl: The influence of tail biting on performance of fattening pigs. Acta vet. scand. 1996, 37, 453-460. - In comparison to 29 non bitten anımals, severe tall biting was found to decrease the daily weight gain (DWG) by $25 \%$ in 8 fattening pigs during the period of biting However, when comparing the weight gain of the lifetıme between bitten and non bitten pigs, no influence of the tall biting was found It is of interest that severily wounded pigs were parenterally treated with prokainpenicillin $\mathrm{G}$ for 3 consecutive days in connection with the tail biting, which could be suggested to promote the growth by reducing the influence of infections gained by the tall biting as well as of other infections present in herds rearıng conventional pigs. Despite penicillin treatment, abscesses were more frequently recorded in tall bitten pigs than in non bitten animals

The tail biting was not equally distributed between the sexes, as barrows were more frequently bitten than gilts Among the unbitten pigs, barrows were also found to grow faster than gilts. Indeed, when comparing tall bitten and non bitten barrows, a negative influence of tail bitıng on DWG was not only shown during the period of biting, but could also be monitored as a reduced DWG from that period unt1l slaughter by $11 \%$ and during lifetıme by $5 \%$ (the tail bitten gilts were too few to allow statistical calculations) These results clearly indicate that tail bitıng affects the growth rate of the lifetıme despite penicillin treatment However, it should be stressed that this decreased lifetime DWG may not be monitored when evaluatıng abattoir data because the sex distribution of the pigs may not be known in such materials.
\end{abstract}

gender; distrubution; abscess.

\section{Introduction}

Tail biting among pigs is frequently observed in pig husbandry. The prevalence of tail biting appears to have increased as the housing systems have intensified the rearing of pigs (Haarbo et al. 1966). Slatted floors (Kelley et al. 1980, Arey 1991, Chambers et al. 1994) as well as poor environment (Sällvik \& Walberg 1984, Chambers et al. 1994) have been reported to increase the incidence of tail biting. Also fasting (Kelley et al. 1980) and other factors that break down the social hierarchy among pigs (Hansen \& Hagelsoe 1980, Ekkel et al. 1995) intense the biting activity. In addition, males are shown to be more frequently tail bitten than females (Penny \& Hill 1974).

The overall economic effects of the tail biting syndrome are not clarified, although the effects of deaths or sanitary slaughters induced by advanced cannibalism and development of abscesses causing partial or full condemnations at slaughter are obvious. In this context, it is also of interest that thrichinellosis is shown to be transmitted to pigs via tail biting (Visnjakow et al. 1972) and that infections with Toxoplasma 
gondii also are suggested to be transmitted this way (Dubey 1988).

In the present study, the performance of tail bitten pigs with that of non bitten pigs was studied in a Swedish farrow to finish herd. In this herd an acute outbreak of severe tail biting occurred as the pigs were aged 10.5 weeks.

\section{Materials and methods \\ Herd and animals}

The study was performed in a conventional farrow to finish herd with 24 sows (Landracex Yorkshire), performing an age segregated production system. Every 11th week, 12 sows farrowed in a previously emptied, cleaned and disinfected farrowing barn with solid floors and straw provided daily. The piglets (Hampshirex Landrace-Yorkshire) were weaned on the same day at a mean age of 5 weeks and stayed in the farrowing pen until the age of 9 weeks. At that age, the pigs were transferred as intact litters to a growing-finishing unit. The pens in that unit consisted of $7.30 \mathrm{~m}^{2}$ solid floor and a dunging area of $1.40 \mathrm{~m}^{2}$ with slatted floor. Each pen of pigs was given $1 \mathrm{~kg}$ straw daily. Within the herd, only one age category of animals was kept per building.

On living day 3 , piglets were intramuscularly injected with iron $\left(200 \mathrm{mg} \mathrm{Fe}{ }^{3+}\right.$, Gleptosil, Fisons, Loughborough, England) and the males were castrated. The iron injection was repeated on living day 14. No tail docking nor teeth clipping was done on the herd. The pigs were fed conventional dry feed without growth promoters (i.e. antibiotics). Until the age of 8 weeks, the pigs were fed a weaning feed (Växfor, Lantmännen, Svalöv, Sweden) and thereafter a gradual change to a fattening feed (Singel Flex, Lantmännen) was made. As the pigs were aged 10 weeks, the weaning feed was totally eliminated.

Four piglets ( 2 barrows and 2 gilts) from each litter $(n=12)$ belonging to a batch of 131 pigs were randomly selected at the age of 6.5 weeks to document the weight gain during the rearing period (see below). Thus, totally 48 animals participated in the study.

Daily weight gain during the rearing period

The initial aim of the study was to monitor daily weight gain in an age segregated production system. To document this, pigs were weighed on a scale (Danvægt 201; Danvægt A/S, Hinnerup, Denmark) every third week from the age of 6.5 weeks until the age of 18.5 weeks. The DWG was estimated on individual basis for each period of 3 weeks (i.e. 4 periods).

In addition, the lifetime DWG was calculated. For this calculation, the live weight at slaughter was estimated to be 1.38 times the carcass weight and the birth weight was estimated to be $1.5 \mathrm{~kg}$. The following formula was used;

Lifetıme DWG $(\mathrm{g}$ per day $)=\frac{[138 \times \text { Carcass weight }(\mathrm{g})]-1,500(\mathrm{~g})}{\text { Age at slaughter }(\text { days })}$

Recording of tail biting and treatment of tail bitten pigs

Tail biting of pigs was recorded by the farmer during daily inspections of the herd. Bitings were classified as severe or mild. Severely tail bitten pigs were injected intramuscularly with $30 \mathrm{mg}$ prokainpenicillin $\mathrm{G}$ per $\mathrm{kg}$ body weight (Penovet ${ }^{\circledR}$ vet, Boeringer Ingelheim Agrovet, Ingelheim am Rhine, Germany) daily for 3 consecutive days and the tails of these pigs were dipped in tar. The treatment was initiated as soon as the injury was discovered. Tail bitten pigs with mild injuries were not medically treated, but their tails were dipped in tar.

Registration of pathological lesions at slaughter At slaughter, pathological lesions (i.e. pneumonia, pleuritis, liver condemnations, arthritis and abscesses) were individually recorded by the 
Table 1. Daily weight gain of pigs exposed to severe tail biting at the age of 10.5 to 11.0 weeks and of non bitten pigs reared in the same faclities.

\begin{tabular}{lccc}
\hline & \multicolumn{2}{c}{ Daily Weight Gain (g per day \pm sd) } & \\
\cline { 2 - 3 } $\begin{array}{l}\text { Time penod } \\
\text { (Age in weeks) }\end{array}$ & $\begin{array}{c}\text { Severely tal bitten pigs* } \\
(\mathrm{n}=8)\end{array}$ & $\begin{array}{c}\text { Non bitten pigs } \\
(\mathrm{n}=29)\end{array}$ & $\begin{array}{c}\text { Level of } \\
\text { significance }\end{array}$ \\
\hline $6.5-9.5$ & $528 \pm 85$ & $493 \pm 106$ & $\mathrm{~ns}$ \\
$9.5-12.5$ & $466 \pm 124$ & $581 \pm 115$ & $\mathrm{p}<0.05$ \\
$12.5-15.5$ & $872 \pm 152$ & $867 \pm 202$ & $\mathrm{~ns}$ \\
$15.5-18.5$ & $1094 \pm 155$ & $999 \pm 200$ & $\mathrm{~ns}$ \\
Birth - slaughter & $625 \pm 38$ & $635 \pm 46$ & $\mathrm{~ns}$ \\
\hline
\end{tabular}

* Severely tail bitten pigs were treated with penicillın for 3 consecutıve days in connection with the tail bitıng.

official registering at slaughter according to rules issued in 1990 by the Swedish Food Administration. As a reference, the mean prevalences for the pathological registrations at the abattoir during the corresponding period were used.

\section{Statistical analysis}

The significance of differences in DWG between groups was determined with the MannWhitney $U$ test and the significance of differences in DWG within groups was determined with the paired Student's t-test, respectively (Version 1.0, Abacus Concepts, Calabasa, CA). The significance for differences in sex distribution between tail bitten and non bitten pigs was analysed by the chi-square test $\left(\chi^{2}\right.$-test).

\section{Results}

Incidence of tail biting during the rearing period

An unexpected outbreak of severe tail biting, possibly initiated by introducing a new batch of feed, occurred when the pigs were aged 10.511.0 weeks. During this period, 8 of the 48 pigs participating in the study were severely tail bitten. Consequently, these pigs were treated with penicillin as described in "Material and meth- ods". These animals are referred to as severely tail bitten pigs ( $n=8 ; 6$ barrows and 2 gilts).

Occasional tail biting was also observed when the pigs were aged 13-18 weeks. During this period, 9 pigs were considered to be mildly injured and one pig was judged as severely bitten (i.e. penicillin treated). These 10 animals are referred to as occasionally tail bitten pigs ( $n=10$; 7 barrows and 3 gilts).

Thirty pigs were not tail bitten. One of these pigs died of microangiopathy (autopsy; Svelab Laboratories, Kristianstad, Sweden) and was withdrawn from the calculations. The remaining animals are referred to as control pigs or non bitten pigs $(\mathrm{n}=29 ; 11$ barrows and 18 gilts).

Daily weight gains during the rearing period Prior to the period of tail biting, the DWG was approximately $500 \mathrm{~g}$ per day for both severely tail bitten pigs and control pigs (Table 1). During the period of intensified tail biting, appearing when the pigs were aged 9.5-12.5 weeks, the DWG of the control animals increased significantly $(p<0.001)$ whereas no increase in DWG was recorded for the severely tail bitten animals. This resulted in a significantly $(p<0.05)$ higher DWG for the non bitten pigs compared to the bitten pigs during the period of 
Table 2. Daily weight gain of gilts and barrows not exposed to tail bitıng during the rearing period.

\begin{tabular}{lccc}
\hline & \multicolumn{2}{c}{ Daily Weight Gain (g per day \pm sd) } & \\
\cline { 2 - 4 } $\begin{array}{l}\text { Time period } \\
\text { (Age in weeks) }\end{array}$ & $\begin{array}{c}\text { Gilts } \\
(\mathrm{n}=18)\end{array}$ & $\begin{array}{c}\text { Barrows } \\
(\mathrm{n}=11)\end{array}$ & $\begin{array}{c}\text { Level of } \\
\text { significance }\end{array}$ \\
\hline $6.5-9.5$ & $499 \pm 101$ & $484 \pm 118$ & $\mathrm{~ns}$ \\
$9.5-12.5$ & $558 \pm 116$ & $618 \pm 108$ & $\mathrm{~ns}$ \\
$12.5-15.5$ & $770 \pm 166$ & $1026 \pm 151$ & $\mathrm{p}<0.001$ \\
$15.5-18.5$ & $894 \pm 176$ & $1169 \pm 89$ & $\mathrm{p}<0.001$ \\
Birth - slaughter & $616 \pm 42$ & $665 \pm 32$ & $\mathrm{p}<0.001$ \\
\hline
\end{tabular}

biting. During the following periods of 3 weeks, both categories of pigs increased their DWG significantly $(\mathrm{p}<0.01$ or $\mathrm{p}<0.001)$. During these periods, no significant differences between DWG of bitten and non bitten pigs were found. Because the onset of tail biting among the occasionally bitten pigs $(\mathrm{n}=10)$ was spread over 5 weeks (pigs aged 13 to 18 weeks), these animals were withdrawn from calculations of the weight gain per 3 week periods during the rearing.

The lifetime DWG (from birth to slaughter) was $625 \pm 38,624 \pm 38$ and $635 \pm 46 \mathrm{~g}$ per day for severely, occasionally and not bitten pigs, respectively. No significant differences in lifetime DWG between the groups was found.

The prevalence of tail bitten individuals was significantly $\left(\chi^{2}=5.24 ; \mathrm{p}<0.05\right)$ higher among barrows (13 out of 24 ) than among gilts (5 out of 23). Since barrows are known to grow faster than gilts (Lundeheim et al. 1980, Lundeheim $1988)$, the DWG of non bitten barrows ( $n=11)$ and gilts $(n=18)$ was compared. Among these animals, the lifetime DWG of the barrows was significantly $(\mathrm{p}<0.001)$ higher than for the gilts (Table 2). This was achieved mainly by a faster $(p<0.001)$ growth of barrows than of gilts during the late fattening period.

Considering this, a comparison between tail bitten and non bitten pigs of the same sex was performed. When comparing the DWG of barrows, a significantly $(p<0.05)$ decreased growth rate was found among the severely bitten pigs $(n=6)$ compared to the non bitten animals ( $n=11$ ) during the period of biting (Table 3 ). This difference tended $(p=0.06)$ to remain during the subsequent period of 3 weeks, but was abolished at the end of the study. Also when assessing DWG from the period of biting until the age of 18.5 weeks $(p=0.055)$ and to slaughter $(\mathrm{p}<0.05)$, respectively, a negative influence of tall biting on DWG was found. The lifetime DWG of the severely tail bitten barrows was $633 \pm 41 \mathrm{~g}$ per day compared to $665 \pm 38 \mathrm{~g}$ per day for the control barrows $(p=0.07)$. When comparing the lifetime DWG for both severely and occasionally tail bitten barrows $(635 \pm 32 \mathrm{~g}$ per day, $n=13$ ) with that of the non bitten barrows, the difference between bitten and non bitten animals was statistically significant $(\mathrm{p}<0.05)$.

No difference in lifetime DWG was seen between the tail bitten barrows $(n=6)$ and the non bitten gilts $(n=18)$. However, the severely tail bitten barrows grew faster than the non bitten gilts at the age of 15.5 to 18.5 weeks $(1133 \pm 154 \mathrm{~g}$ per day compared to $894 \pm 176 \mathrm{~g}$ per day; $\mathrm{p}<0.01)$. The tail bitten sows were to few $(n=2+3)$ to allow statistical calculations.

Pathological lesions recorded at slaughter At the abbatoir, no pathological lesions were registered among the non bitten pigs. In con- 
Table 3. Daily weight gain of barrows exposed to severe tail bitıng at the age of 10.5 to 110 weeks and of non bitten barrows reared in the same facilities

\begin{tabular}{lccc}
\hline & \multicolumn{2}{c}{ Daily Weight Gain (g per day \pm sd) } & \\
\cline { 2 - 4 } $\begin{array}{l}\text { Time peniod } \\
\text { (Age in weeks) }\end{array}$ & $\begin{array}{c}\text { Severely tall } \\
\text { bitten barrows* } \\
(\mathrm{n}=6)\end{array}$ & $\begin{array}{c}\text { Non bitten } \\
\text { barrows } \\
(\mathrm{n}=11)\end{array}$ & $\begin{array}{c}\text { Level of } \\
\text { significance }\end{array}$ \\
\hline $65-9.5$ & $543 \pm 71$ & $484 \pm 118$ & $\mathrm{~ns}$ \\
$95-12.5$ & $458 \pm 145$ & $618 \pm 108$ & $\mathrm{p}<005$ \\
$12.5-15.5$ & $889 \pm 172$ & $1026 \pm 151$ & $(\mathrm{p}=0.06)$ \\
$15.5-18.5$ & $1133 \pm 154$ & $1169 \pm 89$ & $\mathrm{~ns}$ \\
$95-18.5$ & $828 \pm 116$ & $939 \pm 93$ & $(\mathrm{p}=0055)$ \\
$9.5-$ slaughter & $830 \pm 80$ & $931 \pm 71$ & $\mathrm{p}<0.05$ \\
Birth - slaughter & $633 \pm 41$ & $665 \pm 32$ & $(\mathrm{p}=0.07)$ \\
Birth - slaughter $(\mathrm{n}=13)^{\#}$ & $635 \pm 38$ & $665 \pm 32$ & $\mathrm{p}<005$ \\
\hline
\end{tabular}

* Severely tail bitten pigs were treated with penicillin for 3 consecutive days in connection with the tail biting.

\# All tal bitten barrows included ( 6 severely bitten +7 occasionally bitten $)$

trast, abscesses were found in 2 out of $8(25 \%)$ severely bitten pigs and in 3 out of ten (30\%) occasionally bitten pigs. In the latter category, abscesses were recorded in the penicillin treated pig. In another pig of this group, condemned at slaughter, abscesses as well as pneumonia and arthritis were recorded. No other pathological lesions were recorded at slaughter in the animals participating in the study.

In the reference material of the abattoir, the mean prevalences of pathological lesions recorded were $9.2 \%$ pneumonias, $9.0 \%$ pleuritis, $7.1 \%$ liver condemnations, $1.7 \%$ arthritis and $1.2 \%$ abscesses.

\section{Discussion}

Severe tail biting obviously affected the growth of the pigs negatively during the period of biting. The decreased DWG during that period could partly be explained by infections gained by the biting. However, the parenteral treatment with penicillin should at least partly have mini- mized the influence of these infections. Therefore, it appears possible that the discomfort of the animals caused by the biting also influenced the growth rate negatively. This suggestion is supported by the fact that fighting between pigs (Friend et al. 1983) and unpleasant handling (Hemsworth et al. 1987, Hemsworth \& Barnett 1991) are shown to decrease the growth rate of pigs.

Interestingly, the decreased DWG of the bitten pigs during the period of biting was not reflected by the DWG of the lifetime when comparing all severily bitten pigs with all non bitten pigs (i.e. in a sex non defined material). This result corresponds to an earlier study, based on abattoir data, which failed to demonstrate a negative impact of tail biting on lifetime DWG in Swedish pigs (Svendsen et al. 1988). In this context, it is clearly of interest that severely tail bitten pigs in Sweden generally are treated parenterally with antibiotics. This therapy may have 2 effects; a) combating micro-organisms introduced by the tail biting and; b) a systemic 
effect on other micro-organisms present, but not introduced at the tail biting. Within modern rearing of conventional pigs, several unspecified clinical/subclinical infections that influence the growth rate of the pigs negatively are present (Young et al. 1959, Caldwell et al. 1961, Jörgensen 1987, Wallgren 1994). Strategic antibiotic therapy has in many studies been proven to minimize the influence of such infections on growth rate, consequently increasing the DWG of the pigs (Harris et al. 1972, Bakbo \& Szancer 1990, Ibayashi et al. 1990, Pejsak et al. 1990, Schimmel et al. 1990). Therefore, the systemic effect on other infections achieved when tail bitten pigs are parenterally treated with antibiotics could be suggested to compensate for the decreased weight gain in connection with the tail biting.

However, the observation by Penny \& Hill (1974) that barrows more frequently are tail bitten than gilts was confirmed in this study. This might partly be explained by the fact that barrows in general fight for feed (Lund et al. manuscript) and therefore more often attack from behind to get access to the feeding trough, while fighting of females appears to be more correlated to ranking struggles (Rasmussen et al. 1962, Lund et al. (submitted)) in which the animals are confronted face to face. In addition, it is well established that barrows are known to grow faster than gilts (Lundeheim et al. 1980, Lundeheim 1988), which in the present study was evident during the late fattening period. Indeed, when comparing DWG of bitten and non bitten barrows a decreased DWG was found among the tail bitten ones, despite the comparatively few animals participating in the study. This decreased DWG was seen during the period of biting as well as from that period to slaughter. By increasing the number of tail bitten barrows (that is by adding the occasionally bitten barrows to the severely bitten barrows; $n$ $=6+7$ ), also a decreased DWG during lifetime could be shown. Consequently, the negative influence of tail biting on lifetime DWG can only be monitored when evaluating the influence of this syndrome in a sex defined material. Otherwise this influence will be hidden by the disproportionated sex distribution of the tail bitten pigs. For that reason, the negative influence of tail biting on the weight gain may vanish when evaluating productivity from abattoir data, as the sex distribution of the pigs often not is known in those materials.

Another negative effect of the tail biting was the elevated prevalences of abscesses monitored at slaughter. While no abscesses were recorded at slaughter among the non bitten pigs, this lesion was registered in $25 \%$ of the severely bitten (penicillin treated) pigs and in $30 \%$ of the occasionally bitten pigs. These figures also indicate that parenteral treatment with antibiotics for 3 days does not fully protect from infections spread by tail biting, possibly because the lymph nodes to the caudal vertebrae are poorly developed in swine (Hagen \& Skulberg 1960) wherefore infections from the tail rapidly can be spread to other parts of the body.

To conclude, apart from ethical aspects, tail biting causes a decreased growth rate among bitten pigs in connection with the biting. This can also be monitored as a decreased lifetime DWG in affected animals. However, when evaluating abattoir data the decreased lifetime DWG may be hidden by the disproportionated sex distribution of the biting, because more fast growing barrows than slow growing gilts are bitten. Despite penicillin treatment of severely tail bitten pigs, a higher number of abscesses could be expected in this category of animals. Therefore, handling of animals and environmental precautions should be made to minimize the risk for tail biting for both ethical and economical reasons. 


\section{Acknowledgements}

We thank the farmers for letting us perform the study in the herd and Dr. Caroline Fossum for scrutinizing the manuscript. This study was supported by grants from the Swedish Council for Forestry and Agricultural Research.

\section{References}

Are DS: Tall bitıng in pigs. Farm Build. Prog. 1991, no 105, 20-23

Baekbo P, Szancer J. Strategic antibiotic (tıamulin) medication of weaners for Actinobacillus pleuropneumonia Proc. I.P.V.S. 1990, 11, 44.

Caldwell JD, Underdahl NR, Young GA: Swine repopulation, III. Performance of primary SPF pigs on farms. 1961, J. Amer. vet. med. Assoc. 138, 141-145.

Chambers C, Powell L, Wilson E, Green LE. A postal survey of tall-dockıng and tall-biting in South West England. Proc. I.P.V.S. 1994, 13, 475.

Dubey JP. Long-term persistence of Toxoplasma gondii in tissues of pigs inoculated with Toxoplasma gondil oocysts and effect of freezıng on viability of tissue cysts in pork Am. J. Vet. Res. 1988, 49, 910-913.

Ekkel ED, van Doorn CEA, Hessing MJC, Tielen $M J M$. The specific-stress-free housing system has positive effects on productivity, health and welfare of pigs. J. Anim Sc1. 1995, 73, 15441551.

Friend TH, Knabe DA, Tankley TD: Behaviour and performance of pigs grouped by 3 different methods at weanıng. J. Anım. Sc1. 1983, 57, 14061411.

Hagen $O$, Skuleberg A. Halesår hos gris. (Ta1l injuries of pigs) Nord. Vet. Med. 1960, 12, 1-20.

Hansen LL, Hagelsoe AM A general survey of env1ronmental influence on the social hierarchy function in pigs. Acta Agr. Scand. 1980, 30, 388-392.

Harbo K, Hemmingsen L, Schmidt PE, Svendsen P, Westergaard JM. Vulnera morsa caudae suum. Nord. Vet. Med. 1966 18, 441-451.

Harris DL, Glock RD, Dale SE, Ross RF. Efficacy of gentamycin sulfate for the treatment of swine dysentery. J. Am. Vet. Med. Assoc. 1972, 161, 1317-1321.

Hemsworth PH, Barnett JL The effect of aversively handling pigs, etther individually or in groups, on their behaviour, growth and corticosteroids. Appl. Anım. Behav. Sc1. 1991, 30, 61-72.
Hemsworth PH, Barnett JL, Hansen C: The influence of inconsistent handling by humans on the behaviour, growth and corticosteroids of young pigs. Appl. Anim. Behav. Sc1. 1987, 17, 245-252.

Ibayashi T, Ando N, Tanaka T, Kubo M, Yamamoto K, Shimojo T, Yamada K, Yoshioka S, Coulson A. Field studies of the effects of lincomycin feed medication for the treatment of mycoplasmal pneumonias in swine. 1990, Proc. I.P.V.S. 11, 88.

Jörgensen B: Epidemılogıska analyser av sygdomsdata fra svinavlens førsøgsstationer. (Epıdemiological analyses of disease data from pig breeding research stations in Denmark.) Dansk Vet. Tidsknft. 1987, 70, 209-219.

Kelley KW, McClone JJ, Gaskins CT: Porcine aggression: Measurement and effects of crowding and fasting. J. Anim. Sc1. 1980, 50, 336-341.

Lund A, Wallgren P, Rundgren M, Artursson $K$, Thomke $S$, Fossum C. Performance, behaviour and immune capacity of domestic pigs reared for slaughter as siblings or transported and reared in mixed groups. 1996, submitted for publication.

Lundeheim $N$ : Health disorders and growth performance at a Swedish pig progeny testıng station. Acta Agr. Scand. 1988, 38, 77-88.

Lundeheim N, Johansson NK, Andersson K: Estimated phenotypic and genetic parameters based on data from the Swedish pig progeny testing stations. Acta Agr. Scand. 1980, 30, 183-188.

Pejsak Z, Hogg A, Foreman $K$, Wasinska B The effect of Terramycin/LA in combination with Bordetella/Pasteurella vaccine in controlling athrophic rhınıtıs in swıne. Proc. I P.V.S. 1990, 11, 76.

Penny RHC, Hill FWG Observations of some conditions in pig at the abattoir with partıcular reference to tall biting. Vet Rec. 1974, 94, 174-180.

Rasmussen OG, Banks EM, Berry TH, Becker DE Social dominance in gilts. J Anim. Sci 1962, 21, 520-522.

Schimmel D, Blaha T, Erler W, Fuldner M, Burch $D G S$. Combined usage of tiamulin with Pasteurella and Bordetella vaccine against respiratory diseases in a large herd with 7500 breeding sows. Proc. I.P.V.S. 1990 11, 97.

Svendsen J, Olsson A-C, Rantzer $D \cdot$ Productivity and the occurence of disease through to slaughter in pigs with and without reduced vitality or physical handicap at birth. Swedısh University of Agricultural Sciences, Dept of Farm Buldings, Div. of Planning and environments. Report No. 1988, 62, 1-51. 
Sällvik $K$, Walberg $K \cdot$ The effects of air velocity and temperature on the behaviour and growth of pigs J. Agric. Engng. Res. 1984, 30, 305-312.

Visnjakow JI, Georgiev M, Vishnyakov YI Swine caudophagy, a new epizootıological link of trichinellosis in the industrial swine farms. Acta Par. Pol. 1972, 20, 597-604.

Wallgren $P$. The importance of diseases for dally growth in pigs. Proc Nord. Vet. Congr. 1994, XVII:II. 106-110.

Young GA, Underdahl NR, Sumpton LJ, Peo ER, Olsen LS, Kelley GW, Caldwell JD, Adams CH: Swine repopulation I. Performance within a "disease-free" experiment station herd. J. Amer. vet. med. Assoc. 1959, 134, 491-496.

\section{Sammanfattning}

Effekter av svansbitning för produkttviteten hos slaktsvin.

I samband med allvarlig svansbitning noterades en försämrad tıllväxt med $25 \%$ hos angripna djur. I ett 1cke könsdefinıerat djurmaterıal avspeglades dock ej detta 1 den dagliga tillväxten sett över hela uppfödnıngstıden vid en jämförelse mellan svansbıtna och icke svansbitna grisar. I detta sammanhang skall noteras att allvarligt bitna grisar behandlades med penicillinprokain 13 dagar 1 samband med svansbitnıngen. Denna behandlıng skulle kunna tänkas öka tillväxttakten hos de behandlade grisarna genom att reducera inflytandet av infektioner som finns närvarande bland konventionella svin. Trots antibiotıkabehandlıngen resulterade svansbitnıngen 1 en okad inc1dens bölder regıstrerade vid slakt bland de svansbitna grisarna.

Då hänsyn togs t1ll kön visade sıg fler kastrater än sogrisar vara svansbitna. Likaledes växte obitna kastrater snabb̆are än obıtna sogrisar. Vid en jämförelse mellan svansbitna och obıtna kastrater kunde därför ett negativt inflytande av svansbitning noteras inte bara under perıoden för bitning, utan även från denna tıdpunkt fram tıll slakt med $11 \%$ samt för den daglıga tıllväxten från födsel till slakt med $5 \%$ (antalet svansbitna sogrisar var för lågt för att tillåta stat1stıska beräknıngar). Dessa resultat indıkerar att svansbitnıng påverkar tıllvaxttakten hos svin negatıvt, även om djuren antıbiotıkabehandlas 1 samband med denna bitnıng. Resultaten belyser även att denna försämrade tillväxt eventuellt ej upptäcks i samband med utvärderıng av slaktdata eftersom djurens kön vid dessa fall ofta är okänd.

(Recelved November 23, 1995; accepted August 14, 1996).

Reprints may be obtained from: P. Wallgren, National Veterınary Institute, P.O. Box 7073, S-75007 Uppsala, Sweden. fax: +4618 309162, tel: +4618674000. 